and to the Medical Research Council for their kindness in defraying the expense of the animal experimentation.

\title{
BIBLIOGRAPHY
}

Babkin, B. P., and M. E. MacKay.-Amer Jl. of Physiol., Vol. XCI, p. 370, 1930.

Best, C. H. and E. W. McHenry.-Phys Rev., Vol. XI, No. 4, Oct., 1931.

Burn, J. H.-Methods of Biological Assay. Oxford Univ. Press, 1928.

Carrier, E. B -Amer. Jl. of Physiol., Vol. LXI, p. 528, 1922.

Colle, J., P. M. Duke-Elder and W. S. Duke-Elder.-Jl. of Physiol., Vol. LXXI, p. 1, 1931.

Dale, H. H.-Lancet, Vol. I, pp. 1179, 1233, 1285, 1929.

Dale, H. H., and H. W. Dudley.-Jl. of Physiol., Vol. LXVIII, p. 97, 1929.

Dale, H. H., and P. P. Laidlaw.- Jl. of Physiol., Vol. XLI, p. 318, 1910.

Dale, H. H., and P. P. Laidlaw.-Jl. of Pharm. Exper. Therap., Vol. IV, p. 75, 1912.

Dobson, H. V.-Jl. Amer. Med. Assoc., Vol. LXXXIV, p. 158, 1925.

Dubar, J., and Lamache, A.-Bull. Soc. d'ophtal. de Paris, Vol. XLI, pp. 421-3, 1929.

Duke-Elder.-Proc. Roy. Soc., Vol. CIX, pp. 612, 842, 1931.

Friedenwald and Pierce.-Arch. of Ophthal., Vol. III, No. 5, 1930.

Gautier, C.-Compt. rend. Soc. de Biol., 1927.

Hadjimichalis.-Arch. f. exp. Path. u. Pharm., Vol. CLX, pp. 49, 52, 1931.

Hamburger, C.-Klin. Wochenschr., v. 2114, 1926; Klin. Monatsbl.f. Augenheilk., Vol. LXXVI, p. 849, 1926.

Harmer, I. M., and K. E. Harris.-Heart, Vol. XIII, p. 381, 1926.

Harris, K. E-Heart, Vol. XIV, p. 161, 1927.

Knoop, F.-Beit. z. Chem. Physiol. u. Path., Vol. XI, p. 356.

Krogh, A.-Anat. and Physiol. of the capillaries. Yale University Press, 1929.

Lewis, T.-The blood vessels of the human skin and their responses. 1927.

MacKay, M. E.-Amer. Jl. of Physiol., Vol. LXXXII, p. 546, 1927.

Matsuda, A.-Arch. f. exp. Path. u. Pharm., Vol. CXLII, pp. 70-74, 1929.

\section{RICHARD BANISTER \\ Additional facts in relation to the Father of British Ophthalmology}

BY

\section{R. R. James ANd ARNold Sorsby}

\section{LONDON}

SloAne MS. 3801 in the British Museum, published in full in "Studies in the History of Ophthalmology in England prior to 1800 " is of importance because of the wealth of detail about itinerant oculists in the early part of the XVIIth century. It is an anonymous, undated tract which ends abruptly in the middle of autobiographical details concerning its writer. The Museum authorities dated it in the time of Charles the First, and Mr. Harvey Bloom judged its date to be between 1630 and 1640 . The writer speaks of himself as an oculist and mentions his brothers Gabriel and John. He also states that he was trained by his uncle, the author of a "booke of Anathomy." Because of 
the facts that Richard Banister had a " neare and deare kinsman," John Banister by name, the author of an anatomical text-book; and also mentions in his will four sons named Gabriel, Richard, John, and Francis; and in view of the fact that Richard Banister died in 1626, it was suggested in the "Studies" that the writer of MS. 3801 might have been one of his sons. Further search would seem to point to Richard Banister himself as the author of this MS. The following facts deserve attention.

(1) "Ye chefeste oculistes that have bene in this lane or is at this day" as given in the MS. are Luke of Erithe, Mr. Surphlete, Master Barnaby of Peterborough, Earle in Staffordshire, Henry Blackburne and his pupils, Nelson, Page and Hanle.

Personal acquaintance with most of these is indicated in Richard Banister's Breviary; the author relates that he laboured to advance his skill "by the advice of the most skilful in those times; as namely Henry Blackburne, . . Robert Hall, of Worcester, Master Velder of Fennie-Stanton, Master Surflet of Lynne, and Master Barnabie of Peter-Borough."

(2) The writer of the MS. relates that he trained under his uncle " 5 or 6 yeares in ye practice of surgerye atte ye time I was with him I ever collected what receiptes I could and carefully observed alle practise. . . A At Sleaforde where I lived welle for fourteen yeares and carefullye and studyed much my Uncle's booke of Anathomy ... a and I had divers good books of surgerye which I dayly (had) recourse to as occasion was offered in practise ... I made all my medicines myselfe. . ."

In Richard Banister's Breviary the author explains that his " speciall breeding had bene in the general skill of chirurgerie ... at the feet of a Gamaliel ... by name John Banister, my neere and deare kinsman ... (the author of) a booke of anatomie ... labouring to bee as cunning in knowledge of the reason, as perfect in practice . . . I addressed myself to the study of divers best approved authors, as Resis, Mesue, Fernelius, Vesalius, and others." Discussing the "three companions " of " every perfect cure," he states "for the medicines I dayly used, I made them my selfe."

There is much similarity in the extracts given from these two sources. The "booke of Anathomy" is an obvious connecting link. It is very much against the view that the author of the MS. was one of Richard Banister's sons, that the writer makes no mention of his own father. Nor is the suggestion that Richard Banister himself was the author of both documents weakened by the supposition that two of his brothers had the same names as two of his sons. The difficulty of dating the MS. to the time of Richard Banister is overcome if it be antedated by about 15 years. 
This negative evidence apart, there is one fact which is practically conclusive. The author of the MS. states that he lived in Sleaford; at first sight this might seem to point away from Richard Banister, who dated his Breviary from Stamford. But the following extract from Flint South's "Craft of Surgery," edited by Sir D'Arcy Power (London, 1886), p. 152, fully establishes the claim of Richard Banister to a surgical training and confirms the supposition (made in the Short History of Ophthalmology) that the writer who practised for 14 years in Sleaford was none other than Richard Banister, the father of British ophthalmology :

"July 8, 1602. This daye Richard Banister of Slyford in the County of Lyncolne Surgeon was examined and approved before the Masters of this Company by Mr. Wood, Mr. Baker, Mr. Thorney and $\mathrm{Mr}$. Willm. Martin concerninge his skill in the practize of surgery. And he was found an hable (i.e., skilful) and fitt man to use the same."

The evidence available, therefore, points to the author of Sloane MS. 3801 as being a surgeon from Sleaford, who studied under his uncle, and later became an oculist, and wrote and thought very much like Richard Banister, of whom we know that he was a relative and pupil of the celebrated John Banister, the author of an anatomical textbook.

Stamford is only about 25 miles from Sleaford, but being on the North Road would, in Banister's day, have been a more convenient centre for his work as an oculist than a place like Sleaford.

We therefore consider it justifiable to ascribe this interesting MS. document to Richard Banister, who thus puts English ophthalmology still more in his debt.

The following additional facts relative to the Banister family may be inserted here.

In the will of John Markham, gent., dated $26 \mathrm{July}, 160 \pi$, is the following bequest.

"To Mr. Richard Banester in respect of his great paines taken within this my sickness, and of many other kindnesses by him done unto mee, 20 marks." (Maddison's Lincoln Wills, 2nd Series.) In this will the testator describes himself as "one of the sonnes of John Narkham, late of Seidbroke in the County of Lincoln, Esq." We have been unable to locate Seidbroke on the modern map of Lincolnshire, but would hazard the suggestion that perhaps Sedgebrook, near Grantham, and about midway. between Sleaford and Stamford, may be the place in question.

The fact that John Banister was the uncle of Richard enables us, through the kindness of Sir D'Arcy Power, to trace the family pedigree a little further back; though we do not yet know the name of Richard's father. But John Banister was second son 
of John Banister of Cobham, Surrey, Baron of the Exchequer. John Banister, the anatomist, saw military service as surgeon to the forces sent to relieve Havre in 1563, under the command of the Earl of Warwick.

We regret that we are unable to give any further facts about Richard Banister's grandfather. We should have surmised that some details ought to have been forthcoming about a man in his position; but Mr. Harvey Bloom was unable to find his will at Somerset House; though he sent us notes of the wills of four Surrey Banisters of the XVIth century; of these that of John Banester, clerk, parson of Schire (Shere) dated 24 February, 1514, may be a reference to a collateral ancestor. He desired to be buried in the church of the Friars Preachers of Guildford. He mentions his nephew, Robert, and his children, Richard, John, Nicholas, William, Thomas, Oliver, Anne and Agnes. He left a silver cup to the Earl of Surrey and another to Sir John Legh of Stokewell, Knt. The will was proved 14 January, 1516-1ז (P.C.C. 19, Holder). It will be noted that the name of his second son was John.

\title{
VOLUMINOUS ORBITO-CRANIAL OSTEOMA. CONSECUTIVE CEREBRAL ABSCESS, OF NASAL ORIGIN
}

\author{
B Y \\ J. N. Roy, M.D., F.A.C.S. \\ PROFESSOR TO THE UNIVERSITY OF MONTREAL
}

IN 1930, I published the case report of a young girl, who had consulted me for a large osteoma of the orbit. This tumour I had removed by a supra-ciliary incision; and the eye conserved its entire physiological function. Besides this tumour, my patient presented, on the corresponding side, a peripheral facial paralysis, and by elimination of the possible causes, I have classified this affection, which has been cured within four months, as being a frigore. The ethmoid bone had been the point of origin of the neoplasm, and in spite of its radical removal, a relapse came on the same place, a few years later. The great interest of the present case report is that this time the osteoma, originating in the ossification of a fibroma, had at first invaded the orbit, afterwards extended to the cranial cavity, and spread infection to the brain. During operation I discovered a vast abscess of the frontal lobe. Considering these facts, and the medical literature perused, I believe I can say that this case report is the first one ever published on such a subject. This is the history of my patient, 